\title{
Vladimir Stojanović
}

\section{Turizam i održivi razvoj}

\section{Novi Sad, Univerzitet u Novom Sadu, Prirodno-matematički fakultet, Departman za geografiju, turizam i hotelijerstvo, 2011., 260 str.}

\begin{abstract}
"Turizam i održivi razvoj" svojevrsna je dopuna i nadogradnja knjige "Održivi razvoj turizma i životne sredine” iz 2006. godine, dr. sc. Vladimira Stojanovića, sveučilišnoga profesora i znanstvenoga istraživača Departmana za geografiju, turizam i hotelijerstvo Prirodno-matematičkoga fakulteta Univerziteta u Novom Sadu. Knjiga predstavlja autorov nastavak promišljanja mjesta i uloge turizma u godinama koje su pred nama. Turizam u današnjim vremenima, kao i onima koja slijede, trebao bi kreirati nove mogućnosti u okolnostima koje definiramo izazovnima, kada se javljaju ili traju ekonomske krize, a reflektiraju se na sve aspekte života čovjeka. Turizam je sve više usmjeren prema tzv. "pametnom turizmu", koji je čist, ekološki prihvatljiv, etički ispravan i kvalitetan na svim razinama. U tom smislu nužna su, a danas i aktualna i važna, istraživanja odnosa turizma i životnoga okoliša, osobito u kontekstu izrazito razvidnih pozitivnih i negativnih posljedica turističkoga razvoja nekoga prirodnoga i/ili kulturnoga područja. Takva istraživanja vrhunac su doživjela 90-ih godina 20. stoljeća, što se reflektiralo pojavom i inzistiranjem na ekoturizmu i održivom razvoju turizma. Zbog svega navedenoga, udžbenik "Turizam i održivi razvoj" predstavlja rijedak, znanstveno utemeljen i sveobuhvatan pregled istraživanja navedenih tema, prije svega u Srbiji, ali su autorova istraživačka iskustva zanimljiva i za zemlje u regiji, i šire.
\end{abstract}

Predmetni udžbenik podijeljen je u šest poglavlja. U prvom poglavlju Definiranje i objašnjenje osnounih pojmova ekologije $i$ turizma tumače se osnovni pojmovi i pojave neophodni za razumijevanje suštine proučavanja održivoga turizma. Oni su iz područja ekologije, turizma i suvremenih istraživanja u zaštiti životnoga okoliša, a zbog svoje važnosti postali su nezaobilazni, kako u brojnim segmentima suvremenoga života, tako i u turizmu. Posebno je važno ispravno razumijevanje i korištenje navedenih pojmova u istraživanjima turizma zbog vrlo velikoga utjecaja koje turizam ima na životni okoliš, čiji kvalitetni i estetski vrijedni sastojci/elementi čine osnovu turističke ponude regija i zemalja. Istovremeno, degradacija i zagađivanje životnoga okoliša predstavlja opasnost, kako za suvremenoga čovjeka, tako i za turizam. U tom smislu i turizam ima važno mjesto u sustavu očuvanja životnoga okoliša, o čemu svjedoče brojni postupci i akcije koje turistička privreda provodi za njegovo uspješno očuvanje. Drugo poglavlje, Veze turizma $i$ životnoga okoliša, tumači veze turizma i životnoga okoliša kroz tri osnovne vrste utjecaja: ekološke, socijalne i ekonomske, analizirajući njihove pozitivne i negativne strane. Utjecaji turizma na životni okoliš vrlo su kompleksni i tek analiza svih triju navedenih komponenata daje stvar- 
nu sliku o pravom utjecaju turizma na neku destinaciju. Stoga je posebno važno da je s uočavanjem i predviđanjem posljedica nužno osmisliti i provoditi akcije koje će minimalizirati negativne utjecaje i poticati razvijanje onih pozitivnih. Odnos planiranja i organizacije turizma prema zaštiti životnoga okoliša treće je poglavlje, a predstavlja i tumači osnovne tehnike za postizanje ciljeva održivoga turizma: prihvatni kapacitet, granice prihvatljivih promjena, ekološku procjenu utjecaja, zoniranje turizma i etičke kodekse. Planiranje turizma podrazumijeva tehniku, način kako će se turizam integrirati u kontekst općega gospodarskoga i društvenoga razvoja. Kroz taj proces nužno je smanjiti konflikte koji se mogu pojaviti između turizma i ostalih društvenih subjekata. Proces planiranja turizma mora razvijati pozitivan odnos prema životnom okolišu i turističkim resursima, a omogućava da se turizam, promet i komunalna infrastruktura oblikuju u jedinstvenu i skladnu cjelinu. Naposljetku, od planiranja turizma očekuje se da uskladi razvoj turizma s ekološkim kapacitetima životnoga okoliša, kao i onim društvenim i kulturnim. Četvrto je poglavlje pod nazivom Turizam u zaštićenim područjima, s obzirom da se principi razvoja turizma u takvim destinacijama počesto poistovjećuju s principima održivoga turizma. Zaštićena područja jedna su od najaktualnijih destinacija suvremenoga turizma, a odnosi zaštićeno područje - turizam toliko su snažni da se danas upotrebljava pojam "turistička zaštita prirode". U sklopu proučavanja ove teme dr. Stojanović posebnu pozornost posvećuje lokalnim zajednicama koje imaju vrlo važnu ulogu s obzirom da mogu dati značajan doprinos u zaštiti prirode i proširivanju turističke ponude. Autor razlikuje više vrsta zaštićenih područja - nacionalne parkove, rezervate, parkove prirode, predjele divljine, rezervate biosfere i objekte svjetske baštine, ispravno naglašavajući da je organizacija turizma u zaštićenim područjima vrlo osjetljiva i značajno se razlikuje u usporedbi s drugim destinacijama. Ekoturizam - paradigma održivoga turizma peto je poglavlje u kojem se tumači ekoturizam. Autor ističe bitnu poveznicu ekoturizma sa zaštićenim područjima i održivim razvojem, smatrajući ekoturizam paradigmom održivoga razvoja. Na ovome mjestu treba ukratko izdvojiti da se pojava ekoturizma veže za trendove potrošačkoga društva koje je krajem 20. stoljeća postalo zainteresirano, više nego ikada prije, za utjecaj najraznovrsnijih proizvoda na životni okoliš. Prenošenje takvoga stava na turizam rezultiralo je ekspanzijom turizma temeljenoga na prirodi, posebno ekoturizma. On se razvija u ekološki najosjetljivijim područjima, stoga je odgovornost njegovoga kvalitetnog organiziranja veća. Posebno treba biti oprezan u realizaciji ekoturizma jer se vrlo brzo može pretvoriti u nešto posve drugo, a često se sam termin namjerno pogrešno upotrebljava kako bi se prigrabio što je moguće veći dio turističkoga tržišta. Upravo zbog toga u ovom poglavlju pomno se razrađuje predmetna tema, sa zaključkom da je važnost ekoturizma neosporna u zaštiti pojedinih predjela i vrsta, naglašavanju problema lokalnoga stanovništva i skretanju svjetske pozornosti na određene nepravilnosti u životnom okolišu. Posljednje, šesto, poglavlje je Održivi razvoj turizma. U njemu se tumače teorijski aspekti ovoga oblika turizma i sažimaju temeljna načela i principi održivoga turizma koji su utkani u ostala poglavlja udžbenika. S obzirom na negativne posljedice i, općenito, kaotični razvoj, turizam je našao svoje mjesto u okviru održivoga razvoja. Održivi turizam predstavlja koncepciju razvoja koja treba uravnotežiti ekološke, sociokulturne i ekonomske komponente okoliša i zadovoljstvo turista. Taj koncept pomaže pronalaženje optimalnoga oblika turističkoga razvoja koji ne degradira resurse, pa će i buduće generacije biti u mogućnosti zadovoljiti 
svoje turističke potrebe. Središnje mjesto održivoga razvoja je Agenda 21 za turističko gospodarstvo, koja pomaže razumijevanju svih zadataka i izazova u razvoju suvremenoga turizma. Da bi se koncepcija održivoga turizma u cijelosti realizirala, nužno je osmisliti indikatore održivosti temeljem kojih bi se dala konačna ocjena postignutih rezultata turističkoga razvoja. Naposljetku, predstavljenih šest poglavlja zaključuje iscrpan popis korištene literature i izvora.

Udžbenik "Turizam i održivi razvoj" vrijedan je prilog proučavanju turizma, posebno odnosa turizma i održivoga razvoja, temeljen na autorovom sveobuhvatnom znanstvenom istraživanju, terenskoj istraživačkoj praksi, predavačkom iskustvu i odgovarajućem prepoznavanju važnih aktualnih promjena u složenom sklopu raznovrsnih turističkih tema. Pisan jasno i razumljivo, s odgovarajućim znanstvenim aparatom, potkrijepljen određenim brojem priloga, odnosno studija slučaja koji predstavljaju praksu turizma određene destinacije, turizma u zaštićenim područjima, ekoturizma i održivoga turizma, kao i fotografijama, tablicama i grafikonima, ovaj udžbenik predstavlja vrijedno ispitno štivo studentima, te potiče na raznovrsna razmišljanja vezana za obrađenu predmetnu temu. Primjerice, na koji način razvijati pozitivan stav turizma prema životnom okolišu, koje se sve ideje mogu realizirati da bi se na ispravan način turistički shvatili i predstavili životni okoliš i priroda, na što treba paziti da bi se izbjegle greške u procesu razvoja turizma, i drugo. U tom smislu, ovaj udžbenik, osim studentima, namijenjen je i svima onima koje zanima predmetna tema, odnosno onima koji aktivno sudjeluju u planiranju i organiziranju turizma prema načelima održivoga razvoja.

Damir Demonja Institut za razvoj $i$ medunarodne odnose u Zagrebu 